\section{Carlos A. Casanova}

Facultad de Derecho de la Pontificia

Universidad Católica de Chile

ccasanova@uc.cl

ORCID: 0000-0001-9721-7465
Biblica

et

Patristica

Thoruniensia

DOI: http://dx.doi.org/10.12775/BPTh.2021.010

14 (2021) 3: 217-230

ISSN (print) 1689-5150

ISSN (online) 2450-7059

\title{
Saint Thomas Aquinas' Theology and His Commentary on the Book of Psalms*
}

\begin{abstract}
This is a brief commentary of the Spanish bilingual edition of Aquinas' Commentary to the Book of Psalms, by Carlos Casanova and Enrique Alarcón, with the outstanding introductions to each of its four volumes. It deals with the relevance of Biblical studies for the understanding of Aquinas' theological work, the hermeneutical tools used by Aquinas when commenting the Book of Psalms, the contemporary representatives of the school of Biblical Thomism and the main lessons a reader could draw from Aquinas' reading of the Book of Psalms.
\end{abstract}

Keywords: Aquinas' Commentary to the Book of Psalms; Spanish edition; Biblical Thomism; theology and biblical studies.

Holy Scripture lives in the center of a Christian's heart along with the Eucharist. For this reason it is important to learn to read the Scripture as a work whose main Author is God even if its immediate authors were human beings. The best teachers of this kind of reading are the Fathers of the Church ${ }^{1}$. But Aquinas treasured and synthesized their teachings and complemented them with his age's knowledge. That is to say, with a philosophy and a theology that had come to their summit and deserve the adjective "classic." For this reason, to become a disciple of Saint Thomas so as to learn to listen to the voice of the Holy Spirit who speaks through the Bible's pages is a way, not of solving all possible

* This paper is a translation and scholarly expansion of La teología de santo Tomás y el Libro de los Salmos, Humanitas, XVI/97 (2021), pp. 464-473.

1 See P. Roszak. How is the Patristic Method Shaping Sacra Doctrina in Aquinas?, pp. 107-129. On the need of the Fathers for a correct reading of Scripture, see, also, L. Elders, The Presence of the Church Fathers in Aquinas'Commentaries on the Gospel of Matthew and the Gospel of John, p. 284. 
problems posed by textual criticism, but of effectively receiving what is most essential in that reading.

With the purpose of making that discipleship easier to Spanish speakers, Gonzalo Letelier, with great vision, decided to translate into Spanish at the University of Saint Thomas' Center for Thomistic Studies Aquinas' commentaries on the Old Testament, and asked me to undertake the first of these tasks, the Commentary on the Book of Psalms. When Gonzalo left the Center, Ignacio Serrano, his successor, understood the relevance of this project and gave his full support to it. Last year we happily finished this first work, eight years since its conception. ${ }^{2}$ When we began, I knew a bit of its importance but only later did I understand much more thoroughly the following three aspects: (a) the relevance of Aquinas' biblical commentaries in general for the understanding of Saint Thomas' theological work; (b) the central place of the Book of Psalms, among all the Old Testament's Books, in Saint Thomas' estimation; and (c) the extension and depth of Thomistic biblical studies in our time.

Fortunately, we asked Enrique Alarcón to write the Introduction to the first volume and to lead its public presentation in Chile. Enrique wrote an excellent text and in addition conceived the plan of connecting one member of the contemporary biblical Thomistic schools with each of the following volumes. That is how Father Piotr Roszak, from Poland, wrote the introduction to the second volume; Matthew Levering, from the US, the introduction to the third volume; and Jörgen Vijgen, from Belgium, the introduction to the fourth volume. These four literary pieces have great value. In the following pages I am going to introduce the three said aspects and will use these four introductions as my main source. I will close this brief note with (d) a reflection on the main teaching that one can draw, in my opinion, from a careful reading of the Commentario al Libro de los Salmos.

\section{The relevance of biblical studies in general in order to fully understand Aquinas' theological work}

Until the late $13^{\text {th }}$ century the University of Paris' Masters in Theology were Magistri in Sacra Pagina and were focused on commenting Holy Scripture, interpolating in this work the disputed questions, which grew to be to some extent

2 See Tomás de Aquino, Comentario al Libro de los Salmos, tomos I-IV, 2014-2020. 
independent from the commented text. Only the success of Peter Lombard's Sententiae led to the systematic study of theology, but even then it was understood that such study was proper for beginners because the Masters' proper job was commenting the Scripture. This is how one should understand Aquinas' statement in the work itself that the Summa theologiae is a work written for beginners in the study of Theology. "Thomas is a theologian because he sets forth the authentic, divine sense of Holy Scripture. In the Proemium to the Psalms he does not distinguish between biblical and systematic theology, but between 'Holy Scripture and other sciences', that is to say, human sciences. That is Theological knowledge, the one that takes as its premise the divine science expressed in Scripture and set forth by the Magisterium in continuity with the Apostolic tradition." ${ }^{3}$ Similarly, at the very beginning of the Summa theologiae one can see that Aquinas takes as equivalent sacra doctrina (theological science) and Holy Scripture ${ }^{4}$.

Matthew Levering cites Martin Huber and Jean-Pierre Torrell in order to demonstrate that together the Summa theologiae and the Summa contra gentiles have 25,000 Biblical citations and reasonably the majority of them contained in the first of these works. Levering realized that, as far as he can see, only three Biblical books are not cited in the Summa theologiae (Obadiah, Zephaniah and Haggai). In the Part dealing with morality (the Second) this same author counted that 603 chapters of the Old Testament are cited out of the 1,074. This second count he considers as a complement to Servais Pinkaers' work, since Pinkaers strives to rehabilitate the biblical and patristic perspective in Catholic moral theology 5 .

The explanation behind these observations by Alarcón and Levering is clear: theological science is subalternate to divine science. The principles of the former are received from the Teacher par excellence and from other teachers, the saints, who have contemplated and known their truth. They are received through divine Revelation whose deposit is Scripture, lit by Tradition ${ }^{6}$. For this reason a work written not to discuss with gentile philosophers (who only accept the authority of natural reason) but to present the sacred doctrine uses as

3 E. Alarcón, Introducción, pp. 9-25.

4 Cfr. Summa theologiae I q. 1.

5 M. Levering, Introducción, pp. 13-14.

6 P. Roszak, Revelation and Scripture: Exploring Scriptural Foundation of sacra doctrina in Aquinas, pp. 202-208. 
arguments from authority in its sed contra mainly passages from Holy Scripture whose meaning it penetrates with the whole might of the work's rationality, with a Faith searching for understanding.

Since this is so, Aquinas' biblical commentaries have crucial importance because the ground of Thomistic theology lies in his understanding of Scripture. This, I think, is one of the reasons why a strong school of Biblical Thomism has sprung up, for the examination of such ground. But another reason runs, in a way, in an opposite direction. It does not go from the theological work towards Scripture, but vice versa, from Scripture towards the theological work. The recovery of Thomist biblical exegesis leads to a resurrection of Christian life, oppressed for a long time under the yoke of a sterile and pseudo-scientific exegesis founded on prejudices that presuppose a materialist philosophy and/ or a poor natural theology. This second current draws its sap (that nourishes Faith) from the sound assimilation of the Word of God animating the Thomistic biblical commentaries, and from these commentaries approaches the impressive monument of Aquinas' speculative theology.

\section{Centrality of the Book of Psalms among all the Old Testament's Books, in Saint Thomas' estimation. Senses and hermeneutical techniques in his commentary}

Among all the Old Testament's books, the Book of Psalms is perhaps the most cited in Aquinas' theological work. ${ }^{7}$ There are several reasons that explain this preference. I think that one is that the Book of Psalms contains in itself the whole doctrine of the Holy Scripture, also the New Testament's, in such a clear way that Aquinas is moved to state that it looks like Gospel rather than prophecy. ${ }^{8}$ Jörgen Vijgen illustrates this point with an interesting fact: "a third of the citation of the Old Testament in the New Testament are drawn from the Book of Psalms."

7 M. Levering has determined that in the Summa Theologiae's Secunda Pars the Book of Psalms is cited 319 times. The second most cited Old Testament Book is Deuteronomy with 223 citations. See Introducción, p. 14.

8 See saint Th. Aquinas, Comentario al Libro de los Salmos, Proemio, n. 86785, Volume I, p. 33. T.F. Ryan, Thomas Aquinas as Reader of the Psalms, Abstract.

9 J. Vijgen, Introducción, p. 9. 
A second reason is that the Book of Psalms is the backbone of liturgical prayer. As Vijgen explains:

The practice of praying and singing the Psalms became an important part of the Christian life. A critical figure is Benedict of Nursia who in his Rule assigns a central place to the Psalms in his vision of monastic and liturgical life. Early Christian commentators have often pointed out that it is not just the contents of the Book of Psalms that they found attractive but also its emotional effect. Ambrose remarks that although every part of Holy Scripture breathes forth the graciousness (gratiam) of God, it is the Book of Psalms that is especially sweet (dulcis) because, whereas other biblical figures such as Moses would occasionally praise God with songs, it was David who was chosen by God to do so continually in one entire book. John Chrysostom notes: “...nothing so arouses the soul, gives it wings, sets it free from earth, releases it from the prison of the body, teaches it to love wisdom, and to condemn all the things of this life, as concordant melody and sacred song composed in rhythm.." ${ }^{10}$

Saint Thomas was also moved by the poetry of this book, according to a direct witness:

One of his earliest biographers, William of Tocco, reports: "One also saw him often when he was singing the psalm verse during Compline in Lent: 'Do not reject us in old age, when my strength is failing' [Ps. 70: 9], enraptured and consumed by piety, tears streaming down his face that seemed to be bursting forth from the eyes of the pious soul."11

Along this very line one must observe that in the Dominican Order "the public and communal recitation of the Divine Office [... play a] part in the apostolate of the Order." And of Divine Office "the Psalms form its substantial part." $^{12}$

But, a third reason is that Aquinas saw in the Psalms "a soliloquy, a 'conversation of man with God one to one, or speaking within himself alone, because this suits one who praises, and one who prays."'13

10 Ibidem, pp. 9-10.

11 Ibidem, p. 13.

12 Ibidem, p. 13.

13 Ibidem, p. 14. He is citing the Proemio to the Comentario al Libro de los Salmos, Vol. I, p. 35 . 
It should not be surprising, therefore, that Saint Thomas was engaged in commenting the Book of Psalms. In this work he incorporated the whole richness of senses that the Fathers had found in Scripture and developed manifold techniques that we would do well in examining briefly. Father Piotr Roszak explored these senses and techniques in his "Introduction" to the second volume.

Regarding the senses, Roszak shows that they can be either literal or spiritual, and the latter can be allegorical, mystical, moral and anagogical. $\mathrm{He}$ brings to the fore the well known adagio, littera gesta docet, quod credas allegoria, moralia quod agas, quo tendas anagogia. The literal sense is not opposed to the metaphorical but to the spiritual. Only God can insert in his works the spiritual sense because only $\mathrm{He}$ can use not only words but also things, deeds, to reveal Himself to us ${ }^{14}$. Again, the literal sense is the one that the author wanted the words to have, be it the human author, when "he is conscious of transmitting the inspired word" (in which case that is the "literal sense proprius and principalis"), or be it the Holy Spirit alone (in which case "we have a literal sense per adoptionem"). All exegesis must start at the literal sense and arrive at the spiritual, but then turn back to the literal enriching it ${ }^{15}$.

Regarding the techniques, Roszak mentions the following ones: (1) when Aquinas starts the commentary of each psalm, he writes a small introduction and then explains the title. About it, "Thomas attempts to uncover its original, historical sense and, at the same time, its profound sense, in order to set the stage for his main exposition". (2) Divisio textus: “The introductory division of the biblical text in both its levels general (the whole book) and particular (each psalm) is a distinctive characteristic of the scholastic commentary described ordinarily as commentarius continuus and it foretells the way of proceeding and the structure of the exposition. In this kind of commentary, the variety of

14 G. Dahan in Thomas Aquinas: Exegesis and Hermeneutics deals with the relations, distinctions and connections of the four Patristic ways of the spiritual sense and of the literal sense with other hermeneutical tools such as the Augustinian pairing significatio vocum-significatio rerum, the distinction of modi (genera), and the study of metaphor and allegory.

15 See Piotr Roszak, Introducción, pp. 11-14. Also, for all that has been said in the paragraph, see P. Roszak, Exegesis and Contemplation, especially, pp. 483-492. M. A. Tabet delineates a good sketch of Aquinas' understanding of the literal and spiritual meanings: see La perspectiva sobrenatural de la hermenéutica bíblica de santo Tomás, pp. 177-181. One must keep in mind that the literal sense is the meaning that the Holy Spirit expresses with the letter. This is why the Church has taught that Psalm 21 in its literal meaning speaks about Christ and His Passion, as we shall see. 
blocks and simple forms used for the explanation of the text, verse after verse, is subject to the decision concerning the divisio textus particularis. The point is to achieve a global view of the text through all its thematic references and to operate with the small blocks of the biblical text." (3) Glosa: "it is one of the main elements of the commentary [...], ordinarily a short sentence. Its goal is to explain a word and/or a phrase by proposing an interpretation". (4) Notae: "its main goal was to attract the attention to a detail that deserved to be treated more thoroughly. The medieval exegete introduced them (although not always) with the formulae notandum est, nota, or quod sciendum est. Its importance lied in the introduction of a hermeneutical novelty, be it spiritual or literal." 16 (5) Quaestiones: they are unlike the quaestiones of theological works because they are brief. But they fulfill the objective of "solving the doubt that arises during the act of reading by a 'conversation' [...] with alternative views. When reading the Super Psalmos one might have the impression that Thomas' reading consists in asking question after question ${ }^{17}$. Sometimes it is the exegete who asks a question to the text, other times the text addresses a question to the reader and yet other times other exegetes are the ones asking a question. Despite this diversity, Thomas achieves with this a disciplined, organized and systematic commentary" 18 .

\section{Contemporary representatives of biblical Thomism}

It is not my goal with this section to give a complete list of authors, but just to spread among Biblical scholars a handful of names of authors who could serve as links or connections with the wide international movement of Biblical Thomism. In his "Introduction" to volume I of my bilingual edition of Aquinas' Commentary to the Book of Psalms, Enrique Alarcón stated that

since the middle of the $20^{\text {th }}$ century several histories of medieval biblical exegesis were published and they helped to rediscover this important side of the History of Theology. The contemporary movement that promoted going back to the Biblical

16 See P. Roszak, Exegesis and Contemplation, p. 482.

17 P. Roszak deals again with these Quaestiones in The Place and Function of Biblical Citation in Thomas Aquinas'Exegesis, pp. 131-132.

18 P. Roszak, Introducción, pp. 21-25. 
and Patristic sources also helped to come to the result that since the 70s studies on Aquinas' biblical commentaries began to appear in published form frequently. The ourburst, however, in line with the boom of Thomistic studies, took place with the new millennium. ${ }^{19}$

The study of the Biblical aspect of the work of Thomas Aquinas known as Biblical Thomism has crystalized in many authors and in many national contexts $^{20}$. Enrique Alarcón himself is one of its representatives in Spain. In the bibliographical list with which he ends his cited "Introduction," he offers other Spanish or Spanish American names and works. In the first place, Thomas Aquinas' Commentary to Psalm 50 (51) ${ }^{21}$. Besides, Abelardo Lobato Casado, José Loza Vera, Juan Carlos Ossandón Widow, among others. To those we must add Fathers Miguel Ángel Tabet ${ }^{22}$ and David Torrijos-Castrillejo ${ }^{23}$.

The four authors of the "Introductions" acknowledge Martin Morard's important contributions to the edition and commentary of Thomistic Biblical studies in general and, in particular, to the Commentary to the Book of Psalms ${ }^{24}$. They all highlight Jean Pierre Torrell's work as well. We have profited from the translation and French edition of Aquinas' Commentary by Jean-Éric Stroobant de Saint Eloy. Many have profited not little from Gilbert Dahan's research that encompasses Aquinas' Biblical commentaries and stretches beyond to all $\mathrm{Me}$ dieval Biblical commentaries ${ }^{25}$. These names allow us to perceive that there is

19 E. Alarcón, Introducción, pp. 9-10.

20 P. Roszak, J. Vijgen (eds.), Towards a Biblical Thomism. Thomas Aquinas and the Renewal of Biblical Theology.

21 P. Roszak (ed.), Comentario de santo Tomás de Aquino al salmo 50 (51). Traducción y estudios.

22 M.A. Tabet, La perspectiva sobrenatural de la hermenéutica bíblica de santo Tomás.

23 See D. Torrijos-Castrillejo, Santo Tomás como exégeta bíblico en su Comentario al Evangelio de san Juan.

24 An important work by Morard is the electronic edition of the Glosa ordinaria, that is one of the sources most respected by saint Thomas: https://gloss-e.irht.cnrs.fr/php/livresliste.php. See as well: M. Morard, A propos du Commentaire des Psaumes de saint Thomas d'Aquin; and M. Morard, La harpe des Clercs. Réception médiévales du Psautier latin entre usages populaires et commen-taires scolaires.

25 See, for example, G. Dahan, The Editions of Thomas Aquinas's Biblical Commentaries. Their Contribution to Understanding the Text of the Bible during the 13th Century. See also the list of his works here: http://www.etudes-augustiniennes.paris-sorbonne.fr/gilbert-dahan?lang=fr (August $30^{\text {th }}$ 2021). 
a strong French movement of studies, be them scholastic Biblical studies and/ or particularly Thomistic Biblical studies, or be them historical and concerning Medieval Biblical commentaries ${ }^{26}$.

Also in Belgium there are important authors and we must mention Jürgen Vijgen, the author of the "Introduction" to the fourth volume and his mentor, Leo Elders ${ }^{27}$. Piotr Roszak, the author of the "Introduction" to the second volume of the Spanish translation of the Commentary to the Book of Psalms, is working in Poland. And he is spreading the school in that country. Here we have some of the names: Mirosław Mróz ${ }^{28}$, Michał Mrozek, OP, and Marcin Tępczyński ${ }^{29}$. From Italy we can mention other authors such as Inos Biffi, Laura Carnevale, Father Piero Coda, Carmelo Pandolfi, Francesco Santi, and Agostino Selva.

The country with whose Thomistic Biblical scholars I have the strongest ties is the United States. There is a strong movement in this direction. I will mention a few authors. First, Matthew Levering, author of the "Introduction" to the third volume $^{30}$. Then, Joseph Arias, Mark Jordan, John Baptist Ku and Thomas Ryan. Father Thomas Joseph White is probably more of a systematic theologian than a Biblical scholar, but he also has completed excellent works in the area of Biblical Thomism and his Christology sticks very closely to the study of Scripture from a Thomistic perspective. I must conclude mentioning the effort done by DeSales University under the direction of Stephen Loughlin to translate into English the Commentary to the Book of Psalms. ${ }^{31}$

26 P. Roszak, Tomizm biblijny: metoda i perspektywy.

27 L. Elders, “The Presence of the Church Fathers in Aquinas' Commentaries on the Gospel of Matthew and the Gospel of John", p. 257-286.

28 See M. Mróz, "Be Strong in the Lord" (Eph 6: 10). The Role of the Virtue of Fortitude in Christian Life in the Light of the Commentary on the Epistle to the Ephesians by St. Thomas Aquinas.

29 M. Tepczyński, Aquinas's Exegesis of Ps. 51 (50) as a Tool of Christian Education.

30 A magnificent work of biblical tomism is the following: M. Levering, Scripture and Metaphysics: Aquinas and the Renewal of Trinitarian Theology.

31 Available here: http://hosted.desales.edu/w4/philtheo/loughlin/ATP/ 


\section{The main lesson that one can draw from reading the Commentary to the Book of Psalms}

As I close these lines, I want to invite my readers to read the edition we have prepared. As any author of such a large work, I know it contains mistakes and I hope to correct them calmly for a digital edition in the coming years. But, as it stands now, with the Latin text on the opposite page, with the notes to the text of the Psalms ${ }^{32}$ and their commentary, and with the excellent introductions, it is a very good tool to engage in reading the Bible as a work by the Holy Spirit and to understand the deep connection and mutual illumination existing between the Old and the New Testaments. It is truly the Holy Spirit who has "spoken through the Prophets." And it is also the Holy Spirit who can open the Prophets' books to our understanding ${ }^{33}$.

To understand the fullness of the most precious treasures contained in this Master's Work of God's supernatural Love for man is impossible if one does not see in Calvary the fulfillment of the Genesis' protoevangelium, the perfection of all the Old Law's sacrifices, the liberation from the true oppression under sin and satan and, above all, the fulfillment of the old prophecies contained in the Book of Psalms that are not fulfilled in the histories of ancient Israel's Kings but in the promised Messiah. The most impressive text of the Psalms in this sense is Psalm 21; and Aquinas' clearest commentary is the one respecting this Psalm in volume II of this translation. I will copy here a fragment:

As said above, as it happens with other prophets as well, here also some present things are dealt with inasmuch as they are prefiguration of Christ, things that belonged to the prophecy itself. And, for this reason, some times things are said that regard Christ and that go beyond the scope of the histories [that gave occasion to the Psalm].

32 We tried to highlight and consider the most important differences between the Latin text that Aquinas seems to have used, on the one hand, and the Clementine, the Greek, Hieronymus' direct translation from Hebrew, the New Vulgate and Modern translations from Hebrew, on the other. On this subject, one must read G. Dahan's paper: Les éditions des commentaires bibliques de Saint Thomas d'Aquin, pp. 9-15.

33 P. Roszak, Exegesis and Contemplation, p. 485; also, M. A. Tabet, La perspectiva sobrenatural de la hermenéutica bíblica de santo Tomás, pp. $182 \mathrm{ff}$. 
That is to say, in line with what is explained in the Summa theologiae, and with what we have explained when dealing with the senses of Scripture, in prophecy God makes use not only of the prophet's words but also of the actions of historical, real characters who are or can be prefigurations of other events and, above all, of Christ. But when the prophet with his words speaks of such actions sometimes he might go beyond the sense of the histories and then we have clear signs ${ }^{34}$ that they regard the future Messiah. This occurs in the clearest way with the Psalms and, above all, with Psalm 21. This is the reason why Aquinas continues:

And, among other things, this Psalm deals especially with Christ's Passion. And for this reason this is its literal sense. This is why Christ prayed this Psalm during the Passion, when he called: Heli, Heli lammasabactani, that is the same as my God, my God [why have you forsaken me?] etcetera, which is how this Psalm starts. Thus, although this Psalm is said of David in figure, however, especially and according to the letter refers to Christ. And at the Synod of Toledo one called Theodorus Mopsuestuenus was condemned for explaining this Psalm as referring to David according to its letter. For this reason and for many other reasons was he condemned. So, it has to be explained as referring to Christ. ${ }^{35}$

Think about this. We must abandon any naturalistic interpretation, based on a bad natural theology and on bad metaphysics. God is transcendent, eternal, omnipotent and all knowing. Nothing prevents Him from speaking through the effective history as much as through words, concerning what is present and/ or concerning what is future. But, moreover and above this, nobody can understand the Old Testament which would be contrary to God's goodness, if he does not realize that the hatred of the Israelites towards Babylon and her children is the hatred of the Church towards satan and his offspring, sin; if he does not realize that when the prophet speaks of the destruction of the impious he is either foretelling God's judgment or conforming himself to God's justice or desiring the pious revenge that Stephen attained against Paul, as Aquinas points out. It is said so at the commentary to psalm 53, n. 4 (n. 87307), for example.

34 Also the ancient rabbis who were expecting the Messiah around the time of God's Incarnation took these passages as signs of the then future coming. See, for example, Pablo de Santa María, Scrutinium Scripturarum, Distinctiones I-III.

35 Tomas de Aquino, Comentario al Libro de los salmos, Tomo II, p. 261 (n. 86959). 
The person who does not see that His saving design encompasses all of Adam's children and/or does not understand that the promised land and the goods promised by God to his people (Jacob's offspring according to the flesh) are prefigurations of the heavenly Fatherland and of grace and of sanctity, that person has no inkling of the immensity of God's Love. All this is taught in the commentary to Psalms 46 (n. 4) and 43 (n.1), respectively. In the light of all this, it is easy to understand that, for Christians, it is vital to be grafted into the Patristic hermeneutical tradition synthesized, perfected and enlarged with Aristotelian science by Aquinas.

Allow me now to highlight a merit of this edition regarding the Latin text. We do not have yet the critical edition that with so much care Martin Morard is preparing. The text appears in some places corrupted and uncertain. To remedy these problems Enrique and I used the French edition by Jean-Éric Stroobant de Saint-Eloy ${ }^{36}$, and we contrasted it with the text we already had in the Corpus Thomisticum. With much care and with Enrique's guiding judgment, I think we achieved a very trustworthy Latin text.

I finish by inviting our readers to approach the work of the schools of Biblical Thomism in order to nourish their Faith with the sap that comes from its strong Root, that which sprouted from Jesse. That is to say, from Christ, the new Adam, the Word Incarnate, who died for our sins and rose again, the wonder in which Mercy and Justice are condensed and reconciled.

\section{Bibliography}

Alarcón, E., Introducción, in Tomas de Aquino, Comentario al Libro de los Salmos, CETRIL, Santiago, 2014, Volume I, pp. 9-25.

Aquinas, Thomas, Comentario al Libro de los Salmos, , tomos I-IV, trans. and ed. Carlos

A. Casanova, ed. of the Latin text Enrique Alarcón, Centro de Estudios Tomistas of the Universidad Santo Tomás-RIL Editores, Santiago, 2014-2020.

Aquinas, Thomas, Summa theologiae, Universidad de Navarra, Eunsa, Pamplona 2000.

Dahan, G., The Editions of Thomas Aquinas's Biblical Commentaries. Their Contribution to Understanding the Text of the Bible during the 13th Century, Revue des sciences philosophiques et théologiques 89/1 (2005), 9-15. Available here: https://www.cairn.

36 Thomas D'Aquin, Commentaire sur les psaumes. 
info/revue-des-sciences-philosophiques-et-theologiques-2005-1.htm (31 August 2021).

Dahan, G., Thomas Aquinas: Exegesis and Hermeneutics, in: Reading sacred scripture with Thomas Aquinas. Hermeneutical tools, theological questions and new perspectives, P. Roszak, J. Vijgen (eds.), Brepols, Turnhout 2015, pp. 45-69.

Elders, L., The Presence of the Church Fathers in Aquinas' Commentaries on the Gospel of Matthew and the Gospel of John, in: Reading Sacred Scripture with Thomas Aquinas. Hermeneutical Tools, Theological Questions and New Perspectives, ed. Piotr Roszak, Fédération Internationale des Instituts d'Études Médiévales, Brepols, Turnhout 2015, pp. 257-285.

Levering, M., Scripture and Metaphysics: Aquinas and the Renewal of Trinitarian Theology, Blackwell, Oxford 2008.

Levering, M., Introducción in saint T. Aquinas, Comentario al Libro de los Salmos, CETRIL, Santiago, 2018, Volume III, pp. 9-22.

Loughlin, S. (ed.), Commentary on the Psalms, DeSales University, s/f, available here: http://hosted.desales.edu/w4/philtheo/loughlin/ATP/ (27 July 2021).

Morard M., A propos du Commentaire des Psaumes de saint Thomas d'Aquin, Revue Thomiste 96 (1996), pp. 653-670.

Morard, M. (ed.), Glosa Scripturae Sacrae Electronice, Institut de recherche et d'histoire des textes du Centre national de la recherche scientifique, available here: https:// gloss-e.irht.cnrs.fr/php/livres-liste.php (27 July 2021).

Morard, M., La harpe des Clercs. Réception médiévales du Psautier latin entre usages populaires et commen-taires scolaires, Paris 2008.

Mróz, M., "Be Strong in the Lord" (Eph 6: 10). The Role of the Virtue of Fortitude in Christian Life in the Light of the Commentary on the Epistle to the Ephesians by St. Thomas Aquinas, Biblica et Patristica Thoruniensia 3 (2018), pp. 315-330.

Roszak, P., Comentario de santo Tomás de Aquino al salmo 50 (51). Traducción y estudios, P. Roszak (ed.), Cuadernos de Filosofía, Universidad de Navarra, Pamplona 2011.

Roszak, P., Exegesis and Contemplation. The Literal and Spiritual Sense of Scripture in Aquinas' Biblical Commentaries, Espíritu LXV/152 (2016), pp. 481-504.

Roszak, P., How is the Patristic Method Shaping Sacra Doctrina in Aquinas?, in: Reading the Church Fathers with St. Thomas Aquinas. Historical and Systematical Perspectives, P. Roszak, J. Vijgen (eds.), serie BEHE 189, Brepols, Turnhout 2021, pp. 107-129.

Roszak, P., Introducción, in: Saint T. Aquinas, Comentario al Libro de los Salmos, CET-RIL, Santiago 2016, Volume II, pp. 9-27.

Roszak, P., J. Vijgen, Towards a Biblical Thomism. Thomas Aquinas and the Renewal of Biblical Theology, Eunsa, Pamplona 2018.

Roszak, P., Revelation and Scripture: Exploring Scriptural Foundation of sacra doctrina in Aquinas, Angelicum 93 (2016), pp. 191-218. DOI: https://doi.org/10.12775/ BPTh.2016.024 
Roszak, P., The place and function of biblical citation in Thomas Aquinas' exegesis, in: Reading sacred scripture with Thomas Aquinas. Hermeneutical tools, theological questions and new perspectives, P. Roszak, J. Vijgen (eds.), Brepols, Turnhout 2015, pp. 115-139.

Roszak, P., Tomizm biblijny: metoda i perspektywy, Biblica et Patristica Thoruniensia 3 (2016), pp. 119-132. DOI: https://doi.org/10.12775/BPTh.2016.024

Ryan, T. F., Thomas Aquinas as Reader of the Psalms, Dissertation at the University of Notre Dame, Notre Dame 1997 (Accessed through ProQuest through the Library of the Pontificia Universidad Católica de Chile).

Santa María, P., Scrutinium Scripturarum, Junta de Felipe, Burgos, 1591.

Stroobant de Saint Eloy, J.É. (ed.), Thomas D’Aquin, Commentaire sur les psaumes, Les Editions du Cerf, París, 2004.

Tabet, M. A., La perspectiva sobrenatural de la hermenéutica bíblica de santo Tomás, Scripta Theologica 18/1 (1976), pp. 175-196.

Tepczyński, M., Aquinas's Exegesis of Ps. 51 (50) as a Tool of Christian Education, Biblica et Patristica Thoruniensia 3 (2018), pp. 331-344.

Torrijos-Castrillejo, D., Santo Tomás como exégeta bíblico en su Comentario al Evangelio de san Juan, Fortunatae 30 (2019), pp. 225-256.

Vijgen, J., Introducción in: Saint T. Aquinas, Comentario al Libro de los Salmos, CET-RIL, Santiago, 2020, Volume IV, pp. 9-27. 